\title{
A Fatigue and Fracture Study on High Strength Cast Irons
}

\author{
Wilson Luiz Guesser ${ }^{1, a *}$, Luis Carlos Guedes ${ }^{2, b}$, Ailton L. Müller ${ }^{1, c}$, \\ Vagner B. Demetrio ${ }^{3, d}$, Alexsandro Rabelo ${ }^{3, e}$ \\ ${ }^{1}$ Tupy and UDESC - Rua Albano Schmidt, 3400 - 89227-901 - Joinville - SC - Brazil \\ ${ }^{2}$ Tupy - Rua Albano Schmidt, 3400 - 89227-901 - Joinville - SC - Brazil \\ ${ }^{3}$ SENAI - Rua Arno W. Döhler, 957 - 89219-510 - Joinville - SC - Brazil \\ a'wguesser@tupy.com.br, blguedes@tupy.com.br, cailton@tupy.com.br, \\ dvagnerbdemetrio@gmail.com, ${ }^{\mathrm{e}}$ alexsandro.rabelo@sc.senai.br
}

Keywords: Fatigue, Compacted Graphite Iron, Gray Iron, Fractography.

\begin{abstract}
Fatigue strength and fracture of high strength cast irons, gray iron grade 300 and CGI grade 450, used for producing lightweight cylinder blocks, were studied. The results show endurance ratios of $0.27-0.28$ and 0.38 for gray irons and CGI, respectively. The fracture surfaces in cast irons in general show the predominance of graphite and graphite/matrix interface; however, in CGI there is a larger proportion of fractured pearlitic matrix than in gray iron. This fact, and the differences in the morphology of the graphite/matrix interface, flat in gray iron, rough in CGI, explain the higher results of fatigue strength in CGI compared to gray iron. The results of fatigue strength are compared with the literature and with previous works.
\end{abstract}

\section{Introduction}

The trend to lightweight design of automotive engines has led to increased requirements concerning the strength of the alloys used for the production of cylinder blocks. High fatigue strength enables size reduction in structural sections, allowing size and weight reduction in engine blocks, which is particularly critical in automotive engines, in order to reduce fuel consumption and $\mathrm{CO}_{2}$ emissions. For mid-range (6-9 L) and heavy duty engines (11-13 L) increased fatigue resistance also brings the opportunity to increase the power, enabling the use of such engines in new applications.

The advent of the use of compacted graphite iron in engine blocks, replacing gray iron and aluminum alloys, brought new design opportunities, since its mechanical strength (UTS > $450 \mathrm{MPa}$ ) is about twice as presented by gray iron and aluminum alloys (UTS $>250 \mathrm{MPa}$ ). Furthermore, new developments in gray iron metallurgy allowed the large scale production of a higher strength grade (GI 300), providing designers of a new alternative material with low cost. The same trend is observed in higher strength aluminum alloys. However, in these alloys we can't define a fatigue limit, since the fatigue strength for these alloys is always decreasing with increasing number of cycles; technically it is assumed the strength at $10^{7}$ cycles as the fatigue limit.

In the present research, the aim was to characterize the fatigue limit of high strength cast irons. Two different types of gray iron (grade 300) and a CGI grade 450 were selected. The initiation and propagation of the fatigue crack were as well studied, in order to identify critical sites in the microstructure.

\section{Experimental Procedures}

The tests were conducted with two gray irons and one compacted graphite iron, as shown in Table 1. Samples of gray iron were cast in $30 \mathrm{~mm}$ standard bars, while the samples of CGI were produced in 1-inch Y block. Table 1 shows the metallographic characteristics and the tensile test results. It can be seen in Figure 1 that all materials tested had predominantly pearlitic matrix, typical of high strength cast irons. The fatigue tests were conducted on test pieces with $10 \mathrm{~mm}$ 
diameter, according to ASTM E-466-07, in a testing machine INSTRON 8801 with Wave Matrix software, with frequency of $30 \mathrm{~Hz}$, under load ratio $\mathrm{R}=-1$, push-pull. The staircase procedure with step size of $10 \mathrm{MPa}$ was employed, determining the number of cycles to the fracture, with final test at $10^{7}$ cycles.

The fracture surfaces were examined by SEM. The presence of cracks below the fracture surface were also identified, in a section perpendicular to the fracture surface and analyzing the region up to $400 \mu \mathrm{m}$ below the fracture surface. In the samples not fractured, a cut for metallographic examination was conducted on the midpoint of the specimen gage length. Eight metallographic fields were examined in each sample.

Table 1 - Characteristics of the tested cast irons. 4,0-4,1\% Carbon Equivalent.

\begin{tabular}{|c|c|c|l|c|c|c|c|}
\hline Grade & $\begin{array}{c}\text { Alloying } \\
\text { elements [\%] }\end{array}$ & Matrix & Graphite $\left.*^{*}\right)$ & cell/cm & $\begin{array}{c}\text { UTS } \\
{[\mathrm{MPa}]}\end{array}$ & $\begin{array}{c}\text { YS } \\
{[\mathrm{MPa}]}\end{array}$ & HB \\
\hline GI 300 Mo & $\begin{array}{l}0.2 \mathrm{Cr}-0.7 \mathrm{Cu}- \\
0.04 \mathrm{Sn}-0.27 \mathrm{Mo}\end{array}$ & Pearlite & $\begin{array}{l}\text { Lamellar - } \\
\text { Form I }\end{array}$ & 452 & 318 & & 224 \\
\hline GI 300 RG & $\begin{array}{l}0.24 \mathrm{Cr}-0.6 \mathrm{Cu}- \\
0.06 \mathrm{Sn}\end{array}$ & Pearlite & $\begin{array}{l}\text { Lamellar - } \\
\text { Form I }\end{array}$ & 655 & 354 & & 217 \\
\hline CGI 450 & $0.9 \mathrm{Cu}-0.1 \mathrm{Sn}$ & $\begin{array}{c}96 \% \\
\text { Pearlite }\end{array}$ & $\begin{array}{l}\text { Vermicular - } \\
\text { Form III, with } \\
7 \% \text { nodularity }\end{array}$ & 305 & 453 & 347 & 226 \\
\hline
\end{tabular}

$(*)$ - graphite form evaluated according to ISO 945 and nodularity according to ISO 16112 .
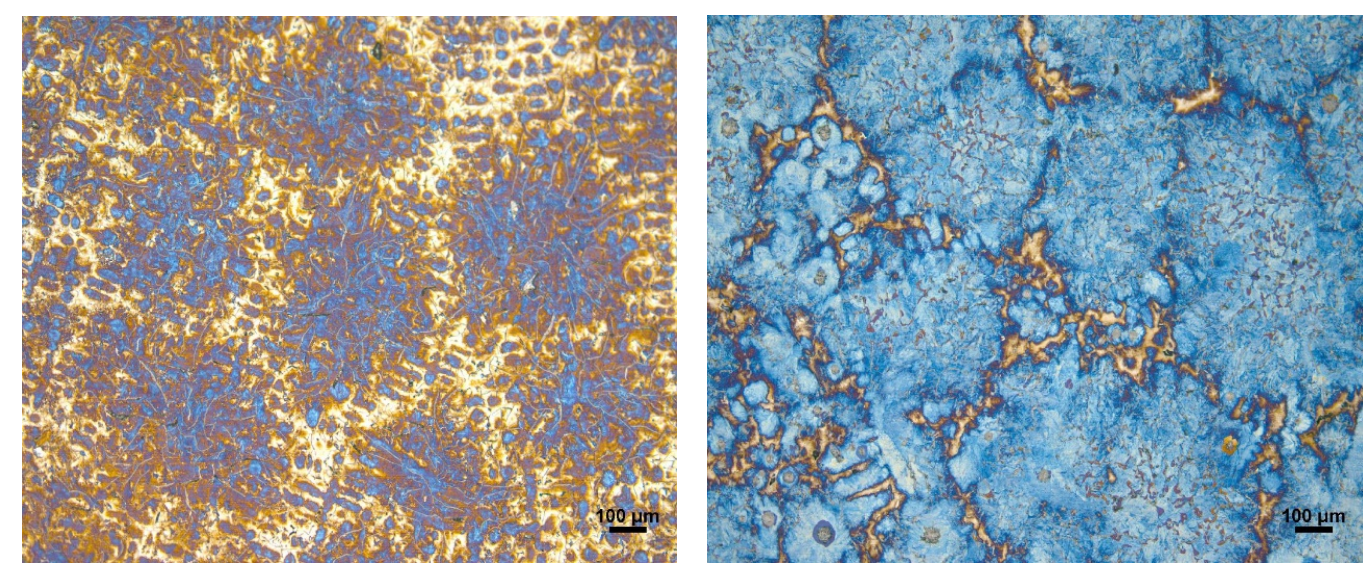

Figure 1 - Microstructure of GI 300 Mo and CGI 450. Color etching (picric acid, $105^{\circ} \mathrm{C}, 3 \mathrm{~min}$ ).

\section{Results and Discussion}

The results of fatigue tests, according to staircase method, are shown in Figures 2 and 3. From these results one obtains the average value of fatigue strength and the standard deviation. The enduration ratio was $0.27-0.28$ for the gray irons grade 300 , and 0.38 for CGI grade 450 .

Figure 4 shows the metallographic analysis below the fracture surface. Cracks were identified, associated with the tips of graphite particles, with sizes of 1 to $50 \mu \mathrm{m}$. Figure 5 shows the quantification of these measures, recording the number of cracks per unit area. It was found that the quantity of cracks is higher in CGI than in gray irons. Some samples did not suffer fracture up to $10^{7}$ cycles (the stress was below the fatigue limit) and, in these samples, it was also possible to observe a large number of cracks, in particular in CGI. This material shows a high resistance to crack propagation. These results confirm the claim of some authors $[2,3]$, that in cast irons the step of crack nucleation occurs very fast, and that the crack growth is going to consume most of the time to fracture. The nucleation of cracks, from the tip of graphite particles, with some plastic deformation connected with the crack formation, is a mechanism of reducing the stress concentration at these locations, so that once the peak stress is relieved, the crack remains stable. Only when increasing the stress, the crack can grow and lead to the final fracture of the sample. 

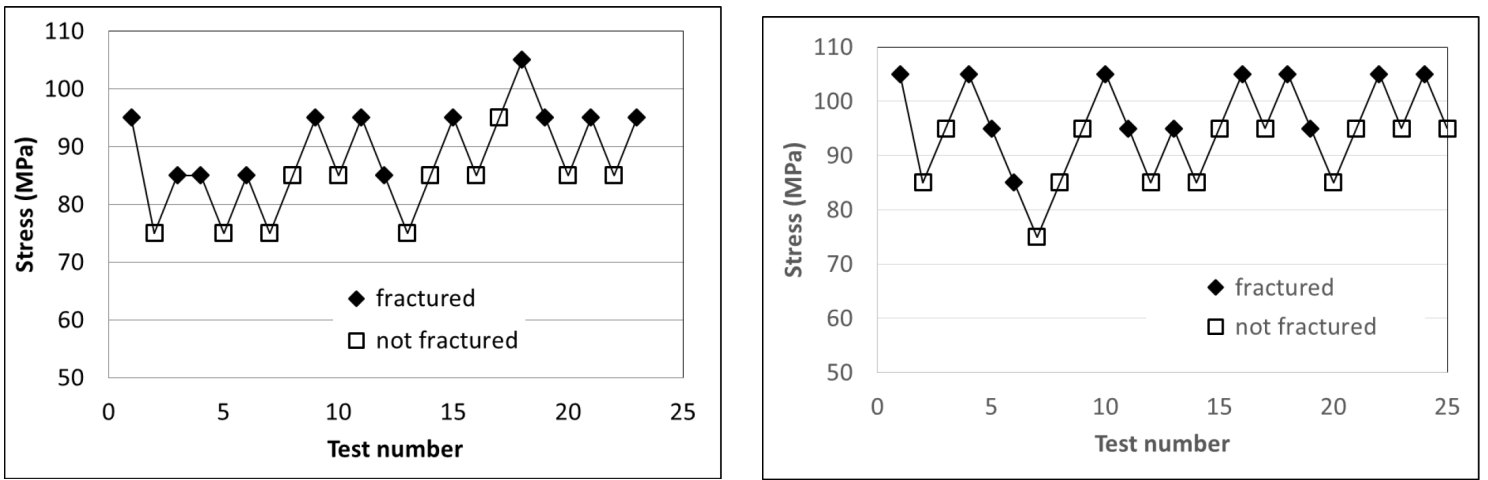

Figure $2-$ Results of staircase fatigue testing for gray irons grade 300.

a) GI $300 \mathrm{Mo}$ alloyed. Fatigue strength $=88 \mathrm{MPa}(\mathrm{s}=6.3 \mathrm{MPa})$. Endurance ratio $=0.28$.

b) GI $300 \mathrm{RG}$. Fatigue strength $=95 \mathrm{MPa}(\mathrm{s}=7.2 \mathrm{MPa})$. Endurance ratio $=0.27$

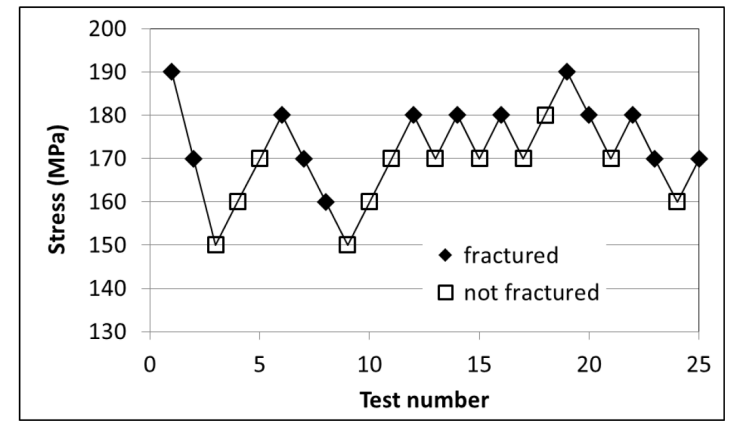

Figure 3 - Results of fatigue testing of CGI grade 450 . Fatigue strength $=171 \mathrm{MPa}(\mathrm{s}=10.1 \mathrm{MPa})$, Endurance ratio $=0.38$.

Figures 6 to 9 show typical fractographies of gray iron samples. Note the fracture of the matrix, with fatigue striations, the graphite fracture and the fracture of the graphite/matrix interface. It can be observed in the fractured surface that the fracture of graphite and of graphite/matrix interface predominates, as they are places of low-resistance (Figure 6). The fatigue fracture of the pearlitic matrix must be differentiated from the fracture in continuous loading, as in the tensile test, where the result of plastic deformation of ferrite lamellae can be clearly seen, resulting in rougher surface (Figure 7-a). Graphite fracture shows the structure of plates (Figure 8). In regions where fracture occurred in the graphite/matrix interface, it is observed that the metallic matrix shows the surface characteristics of the graphite (figures 6 and 9), suggesting that the graphite was formed before the matrix. In fact, the solidification growth of the eutectic graphite/austenite occurs with graphite as the leading phase, allowing the austenite to solidify over the graphite already formed.
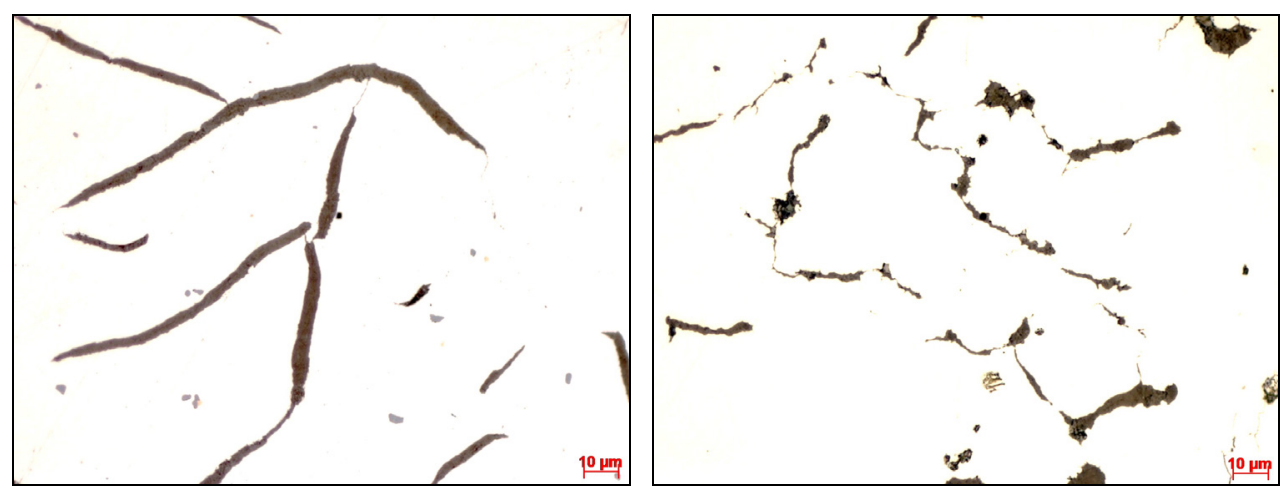

Figure 4 - Metallographic sections at $400 \mu \mathrm{m}$ under the fractured surface, showing cracks associated with graphite particles. (a) GI $300 \mathrm{RG}$ - $105 \mathrm{MPa}-387,731$ cycles. (b) CGI 450 - 180 $\mathrm{MPa}-7,293,925$ cycles. 


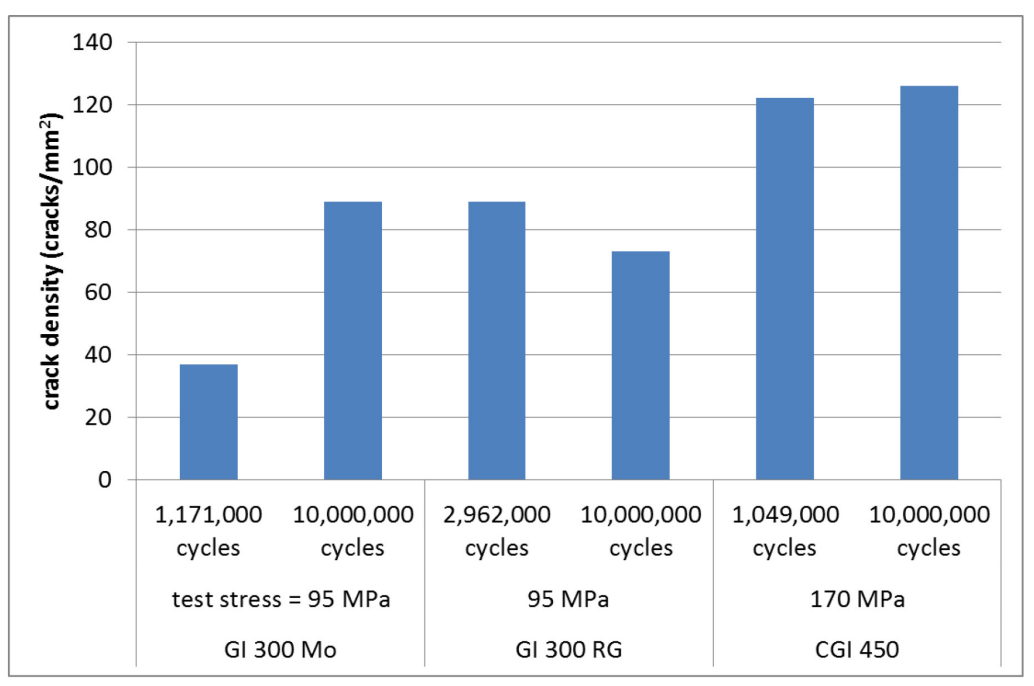

Figure 5 - Crack density up to $400 \mu \mathrm{m}$ under the fracture surface (for fractured samples) or up to $400 \mu \mathrm{m}$ from the middle of the fatigue sample (non fractured samples at $10^{7}$ cycles).

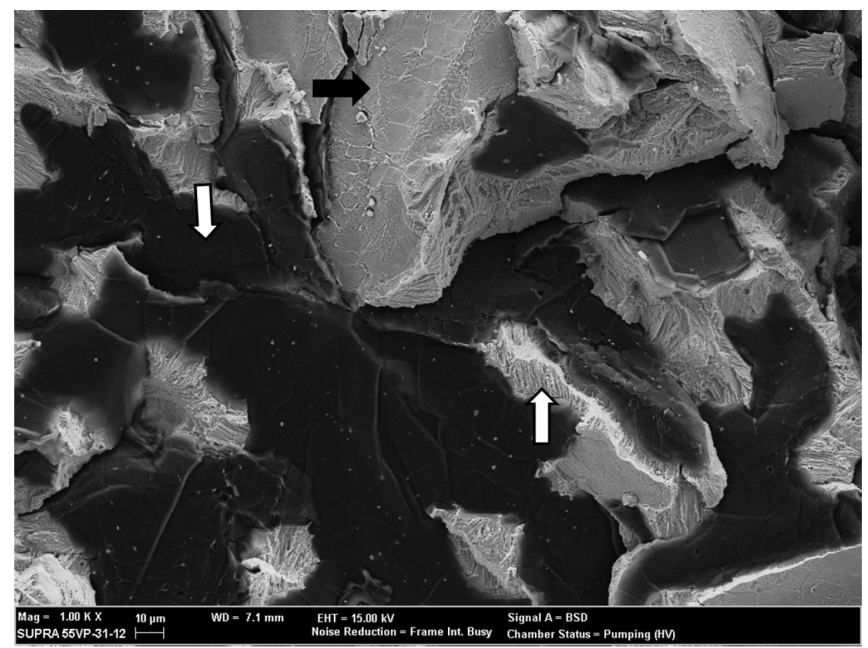

Figure 6 - GI $300 \mathrm{Mo}-95 \mathrm{MPa}-6,000,000$ cycles. Fracture of the pearlitic matrix (white arrow, up), of the graphite (white arrow, down) and of the graphite/matrix interface (black arrow). Most of the surface fracture shows graphite and graphite/matrix interface. Only $24 \%$ of the fracture surface area is matrix fracture.
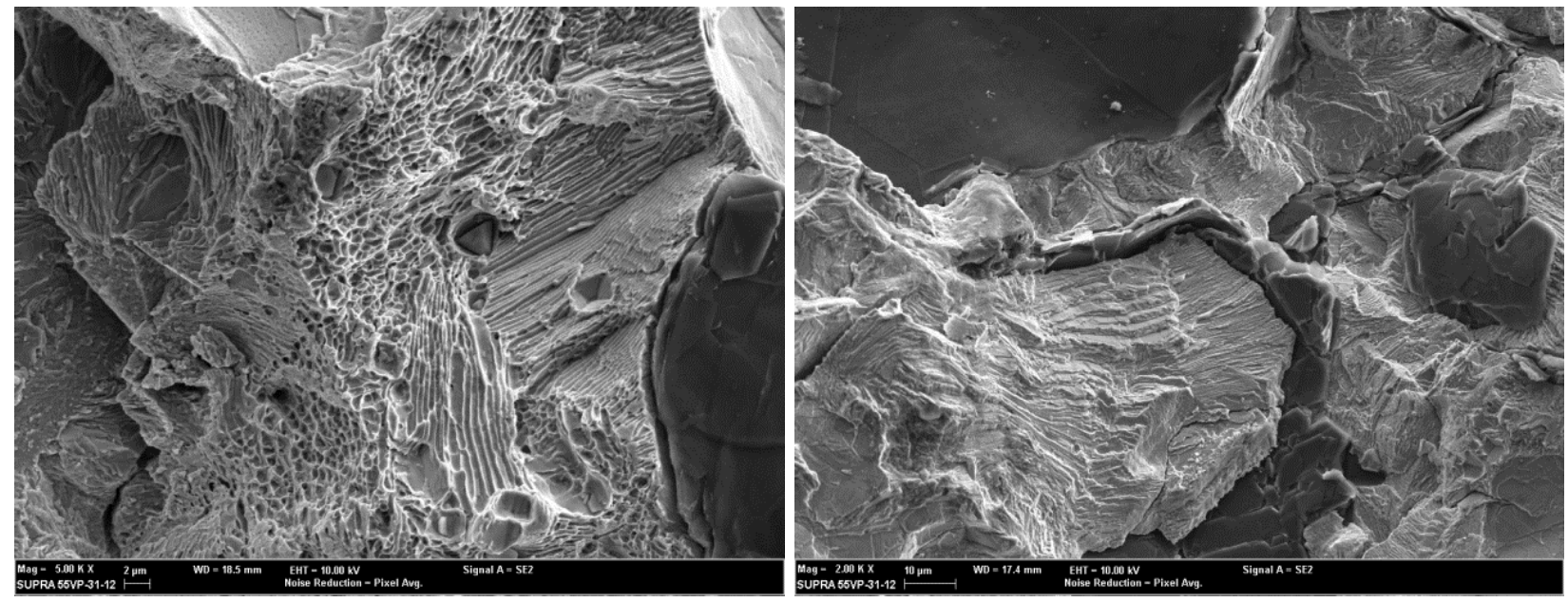

Figure 7 - Pearlitic matrix fracture in tensile testing (a) and fatigue testing (b). GI 300 RG. 


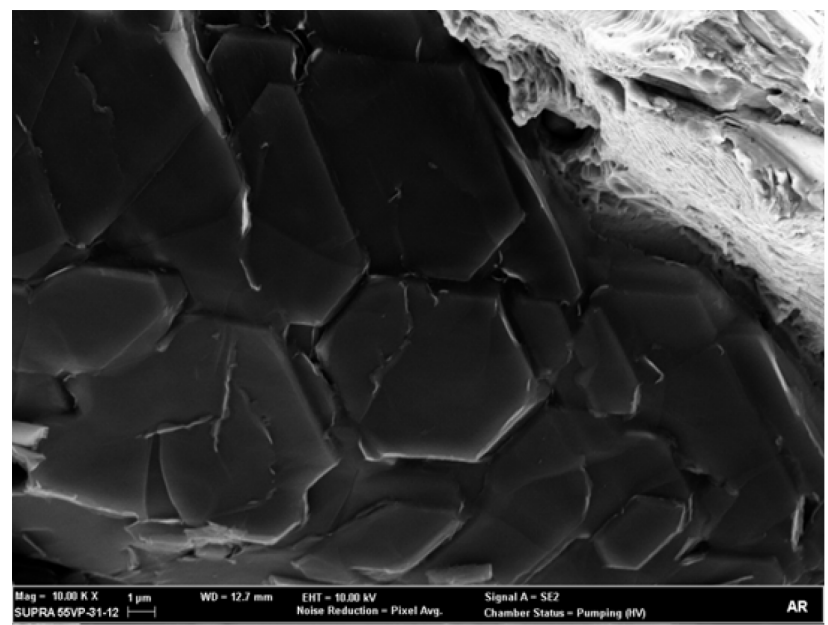

Figure 8 - Fracture of graphite particles, showing in some cases the plate structure. GI $300 \mathrm{Mo}-95 \mathrm{MPa}-337,540$ cycles.
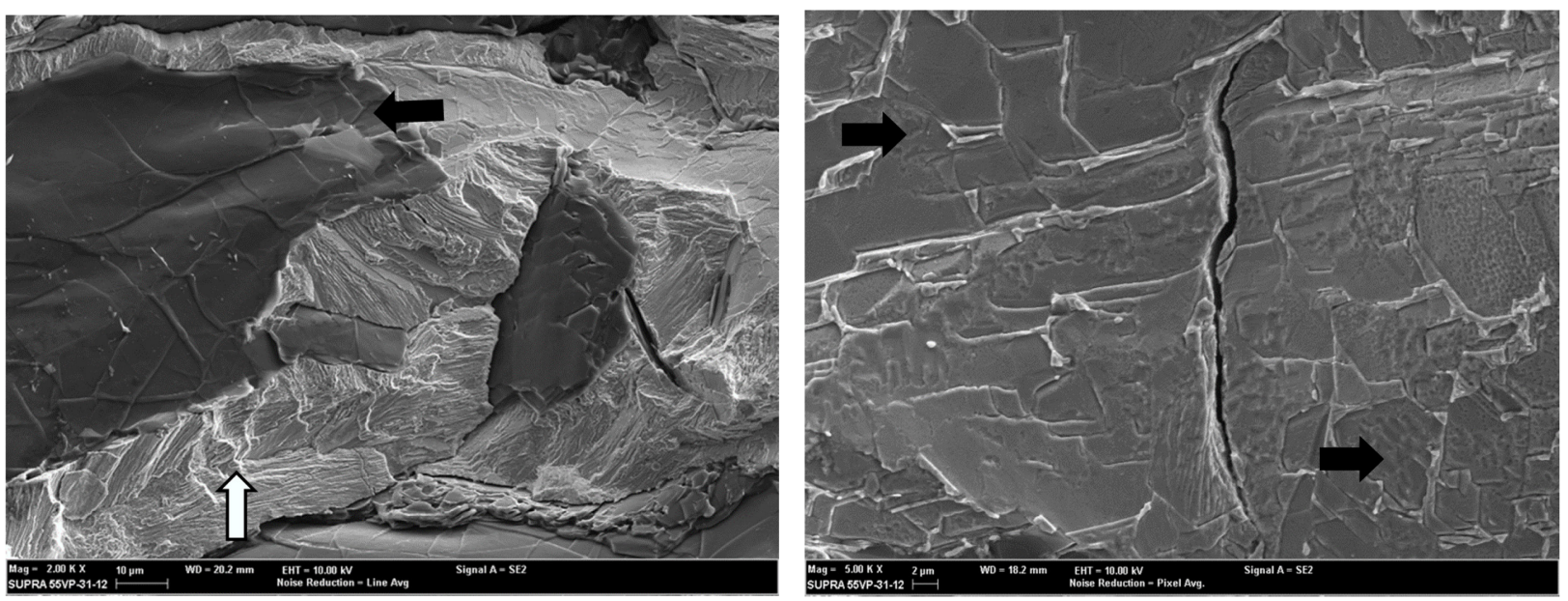

Figure 9 - Fracture of the matrix (white arrow, up) and on the graphite/matrix interface (black arrow). GI $300 \mathrm{RG}$ - $95 \mathrm{MPa}$ - 337,540 cycles (a) and 9,211,676 cycles (b).

In CGI fractures less graphite areas are observed than in gray iron (Figures 10 and 6, respectively). In addition, a smaller area of graphite/matrix interface than in gray irons is also observed. Furthermore, this interface, revealed by the printing of the matrix against graphite, is rougher than in gray iron. The graphite in CGI consists of a stacking of plates with different orientations (Figure 11-a). In consequence, the graphite/matrix interface presents rougher surface than in gray iron, thus providing additional difficulties for fatigue crack propagation along these interfaces. Additionally, in gray iron the graphite shape, as continuous plates throw the eutectic cell, helps a crack to growth easily through a eutectic cell, and the main resistance to the crack propagation is the continuous matrix at the cell boundaries. In CGI the graphite shape, with thick irregular plates and rods, creates additional difficulties for the crack propagation. The crack propagation must cause disruption of the metal matrix not only along the cell boundaries, as in the case of gray iron, but also inside the eutectic cell, between the graphite rods. Thus, the amount of metallic matrix that can be observed in the fracture surface is greater in CGI than in gray iron (Figures 10 and 6, respectively), what helps to understand the greater fatigue strength of CGI as compared to gray iron. Figure 11-b shows a continuous area of pearlite fracture, probably a dendrite of previous austenite.

The results of fatigue strength for the two tested gray irons were compared to values determined in previous work, in samples taken from an I6 engine block [1], with results of the ISO 185 standard [4] and from the literature [6,7], as shown in Figure 12. The values of fatigue strength are closer to an endurance ratio of 0.29 , higher than established in the ISO Standard (endurance ratio $=0.25$ ). 


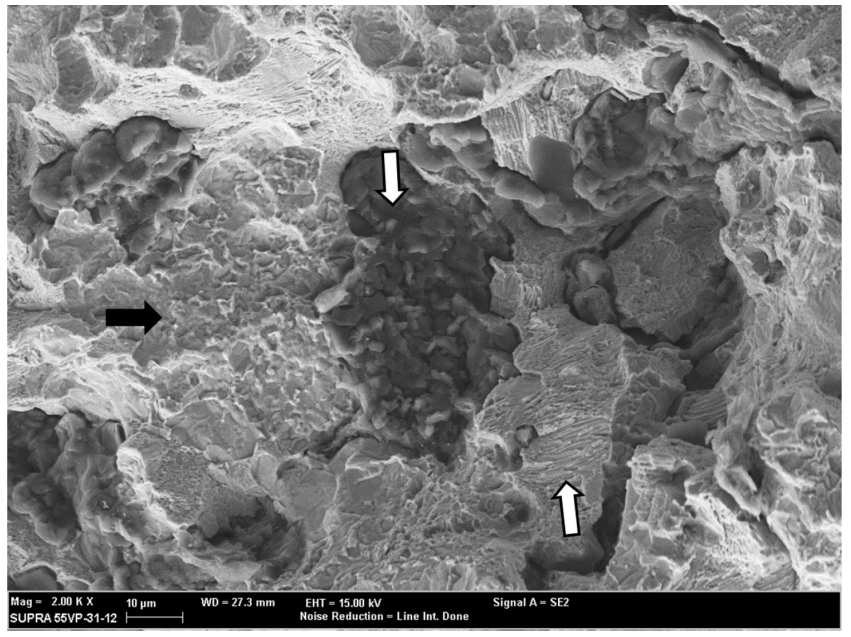

Figure 10 - CGI 450. Fracture of the graphite (white arrow, down), of the matrix (white arrow, up) and of the graphite/matrix interface (black arrow). Some secondary cracks. This fracture shows

$43 \%$ of the total area as fracture of the pearlite matrix. $180 \mathrm{MPa}-7,293,925$ cycles.
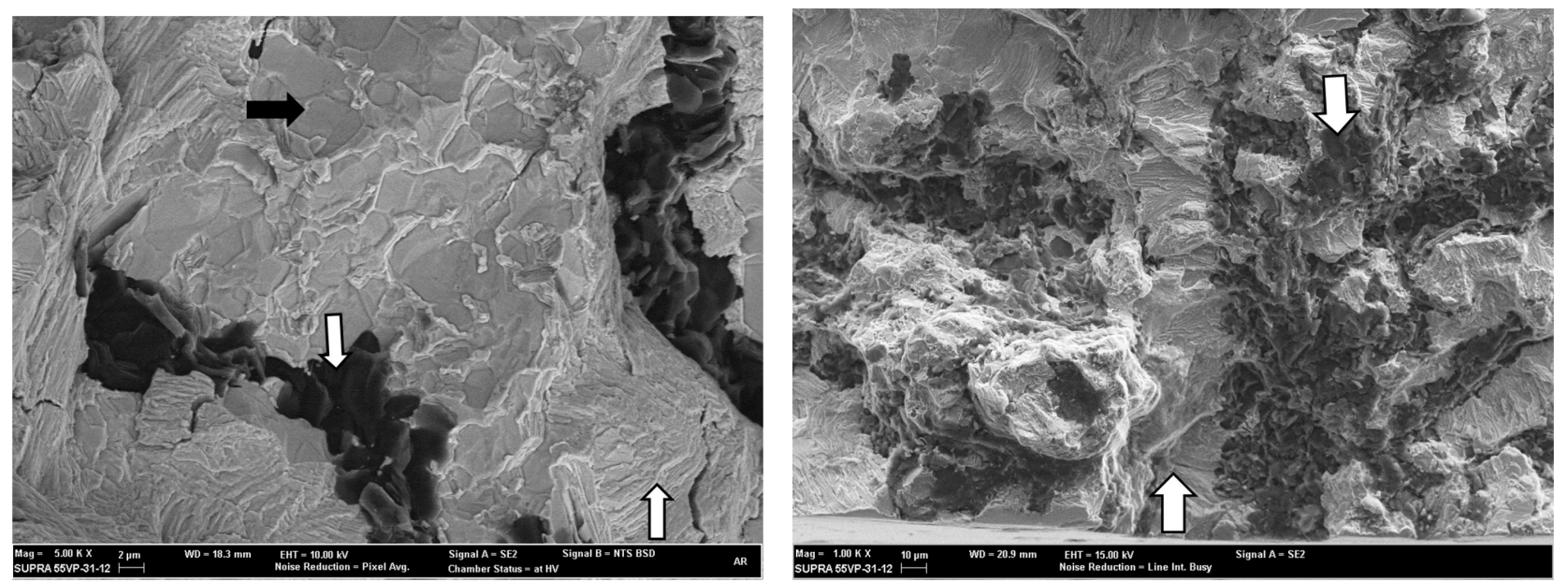

Figure 11 - Fracture of the graphite (white arrow, down), of the matrix (white arrow, up) and of the graphite/matrix interface (black arrow). CGI 450. (a) $180 \mathrm{MPa}-7,293,925$ cycles. (b) $170 \mathrm{MPa}$ $1,049,212$ cycles.

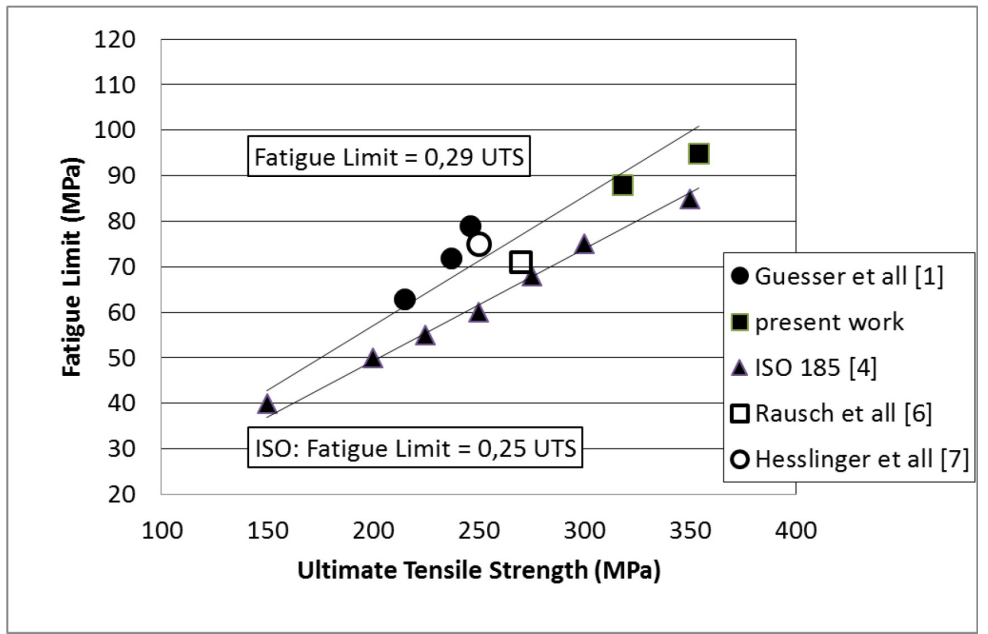

Figure 12 - Fatigue results for gray iron from the present work, compared with previous work and with ISO 185:2005. Push-pull, R=-1.

The fatigue strength results for CGI determined in this study were compared with values from the literature [11-13]. Figure 13 shows the relationship between fatigue limit and UTS for compacted graphite irons. The endurance ratio values are close to 0.38 . The same endurance ratio of 
0.38 will result if we take only the results from UTS of 450 to 530 MPA. This value is significantly higher than that recorded for the gray irons (0.29), and shows that in compacted graphite iron increments in tensile strength translate into considerable increase in resistance to fatigue. This is attributed to the graphite morphology in CGI, as discussed before.

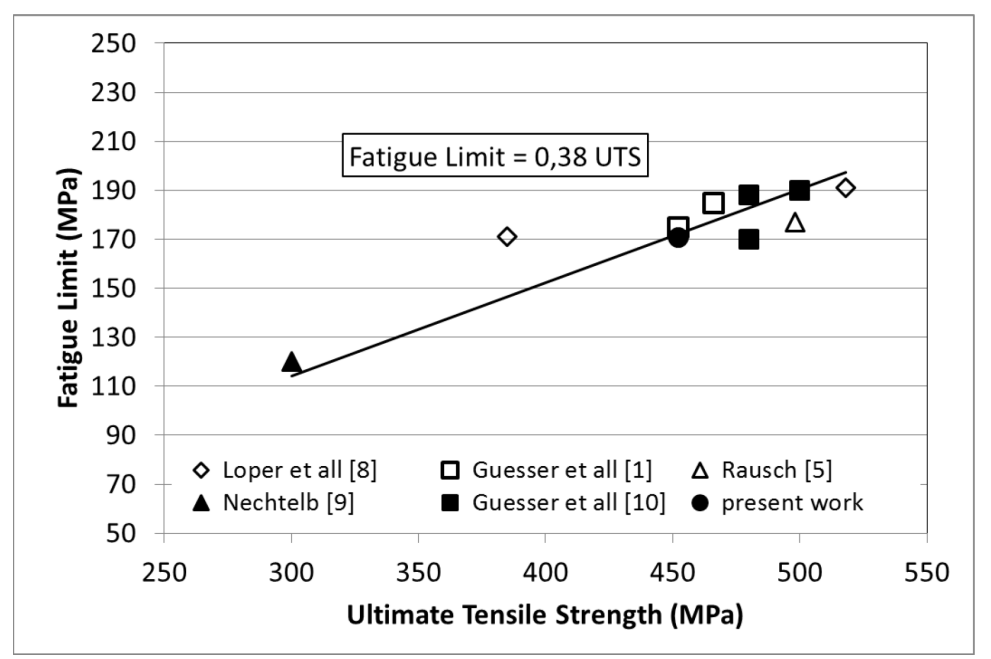

Figure 13 - Fatigue results for CGI from the present work, compared with previous work and with the literature. Push-pull, $\mathrm{R}=-1$.

Comparative results are also shown in Figure 14, which gathers information from this study and previous work $[1,10]$. These results show the development of new classes of cast irons of higher strength. The increase from the standard gray iron grade 250 (fatigue limit of $80 \mathrm{MPa}$ ), traditionally used for cylinder blocks, to the CGI grade 450 (fatigue limit of 170-190 MPa) can be seen, offering in this way opportunities for the design of lightweight engines.

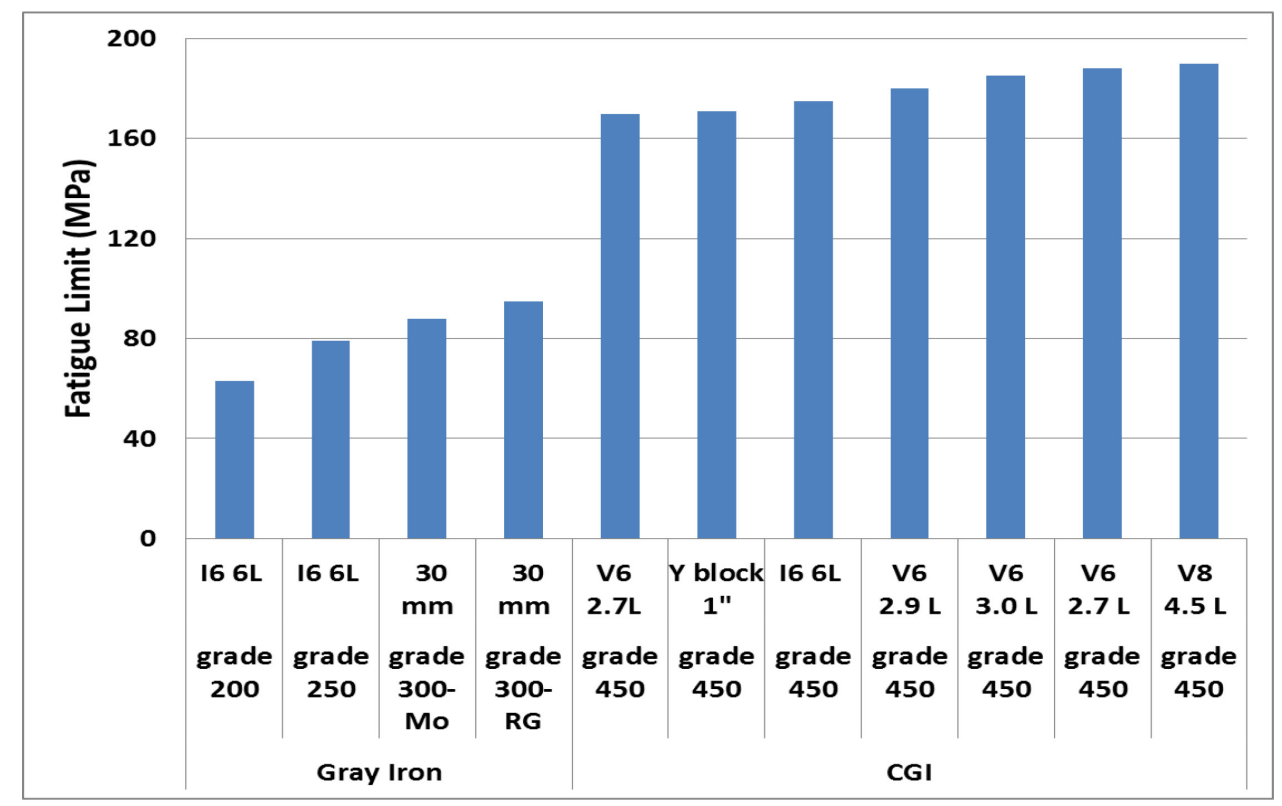

Figure 14 - Fatigue limit results for gray irons and CGI. Results from the present and previous works $[1,10]$.

\section{Conclusions}

Based on the experimental results, it can be concluded that:

- Gray iron grade 300 shows fatigue strength of 88 to $95 \mathrm{MPa}$, with an endurance ratio of $0.27-0.28$, while CGI grade 450 showed fatigue strength of $171 \mathrm{MPa}$, with an endurance ratio around 0.38 . 
- Metallographic sections under the fracture surface, in gray iron and CGI, show the presence of cracks associated with the graphite particles, with sizes of 1 to $50 \mathrm{um}$. The quantity of cracks is higher in CGI than in gray irons.

- The same was observed in sections performed on samples subjected to 10 million cycles without failure, therefore subjected to stresses below the fatigue limit. These specimens also have a large number of cracks, particularly in CGI, showing that this material displays a higher resistance to crack propagation. It also indicates that in cast irons the step of crack initiation occurs very fast and in many places, and the crack growth is going to consume most of the time to fracture.

- The fracture surfaces of gray iron samples show that the cracks propagate mainly by the graphite skeleton (graphite and graphite/matrix interface), so that the fracture surface displays only $20-25 \%$ of fractured metallic matrix. The fractured graphite/matrix interface shows the array with relief of the graphite, with large flat areas and small crevices.

- The CGI samples show a large percentage of the metallic matrix on the surface fracture (40-45\%), reflecting the greater difficulty of crack propagation in this cast iron. The graphite/matrix interface revealed by the fracture was very rough, which is the result of the graphite structure.

\section{Acknowledgments}

The experiments reported in this paper were conducted in the partnership with Tupy and SENAI Innovation Institute for Manufacturing Systems.

\section{References}

[1] W. L. Guesser, I. Masiero, E. Melleras, C. S. Cabezas. Fatigue strength of gray iron and compacted graphite iron used for engine cylinder blocks. SAE Brasil, 2004-01-2222, 2004.

[2] D. F. Socie \& J. Fash. Fatigue behavior and crack development in cast iron. AFS Transactions, 90 (1982) 385-392.

[3] M. Mörtsell, K.Hamberg, J. Wasén. Crack initiation in ductile cast irons. Int J Cast Metal Res, 16 (2003) 245-250.

[4] ISO 185. Grey cast irons - Classification. 2005.

[5] T. Rausch. Zum Schwingfestigkeitsverhalten von Gusseisenwerkstoffen unter einachsiger und mehrachsiger Beanspruchung am Beispiel von EN-GJV-450. Doktor Dissertation. RWTH Aachen, (2011).

[6] T. Rausch, P. Beiss, C. Broeckmann, S. Lindlohr, R. Weber. Application of quantitative image analysis of graphite structures for the fatigue strength estimation of cast iron materials. Procedia Engineer, 2 (2010) 1283-1290.

[7] M. Hesslinger, J. Böhme, F-X. Epping, A. Lembach, K. Friedmann, J. Achenbach, M. Garza. Erstes GJV-Zylinderkurbelgehäuse für hoch aufgeladene direkt einspritzende Ottomotoren, VDIBerichte Nr. 2061: Gießtechnik im Motorenbau, Anforderungen der Automobilindustrie.VDIVerlag. (2009) 269-288.

[8] C.R. Loper, M.J. Lalich, H.K. Park, A.M. Gyarmaty. The relationship of microstructure to mechanical properties in CGI. AFS Transactions, 90 (1982) 313-330.

[9] E. Nechtelberger: The properties of cast iron up to $500^{\circ} \mathrm{C}$. Technicopy Ltd, England (1980).

[10] W.L. Guesser \& E. Melleras. Fatigue tests on CGI samples. V8 Cylinder Blocks. Tupy Internal Report (2007). 